May 16-22

Fourth Bi-annual Colloquim of Creole French Studies in Lafayette, Louisiana, USA.

Theme: Creole-French and Regional French Varieties. Information: Professor D. Barry, Department of Foreign Languages, University of Southwestern Louisiana, P.O. Box 43331, Lafayette, Louisiana 70504, USA.

May 23-25

Fourteenth International Colloquium of AIMAV (Association Internationale pour la Recherche et la Diffusion des Methodes Audio-Visuelles et Structuro-Globales) in Paris, France.

Theme: the Teaching of Arabic to Adults (including migrants) in Europe.

Information: AIMAV, University, Faculty of Philosophy and Letters, Blandijnberg 2, B-9000 Chent, Belgium.

\title{
June 1-3
}

Colloquium on problems of linguistic and literary computing in France in Metz, France.

Information: C. Charpentir, 30, rue Saint-Paul, F-57158 Montigny Les Metz, France.

June 6-12

Second International Conference on Minority Languages in Turko/Abo, Finland.

Theme: Minority Languages, Language Planning and Language Preservation.

Information: Nordisk Spraksekretariat, Postboks 8107 Dep., Oslo 1, Norway.

\section{June 9-11}

International Conference on Complementation in Brussels, Belgium. Information: Professor Dr. Y. Putseys, Contact and Documentation Centre for Flemish Linguistics, University, Vrijheidslaan 17, B-1080 Brussels, Belgium.

\section{June 20-22}

Symposium of the International Federation of Teachers of French (FIPF) in Sevres, France.

Theme: French as a Foreign Language.

Information: FIPF, Secretariat, 1, avenue Leon Journauet, F-92310 Sevres, France. 
The versatile Audio Classroom 200 is capable of all levels of language teaching. The economical, modular design allows easy expansion to accommodate up to ten program sources.

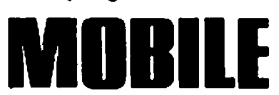

The Mark1A is a complete LevellI

200

Telex Communications, Inc. is a primary manufacturer of educational audio visual products, including Language Labs. Over the years, the on-the-job performance record of these language lab products has earned Telex an enviable reputation for quality and integrity. They are developed and produced in the USA and are sold. installed and serviced by local factorytrained and authorized Tolex Languago Lab dealers.

Write for exciting details

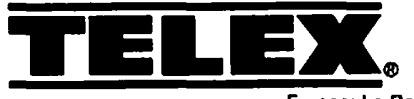

TELEX COMMUNICATIONS, INC. Europe: Le Bonaparta - Office 711, Centre Affaires Paris-Nord, 93153 Le Blanc-Mesnil, France

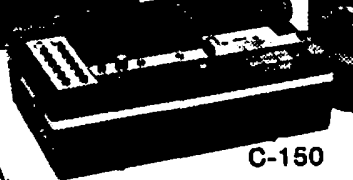

$\mathrm{c}-150$ The C-150 offers the lowest possible initial
investment plus the flexibility to expand
into a full, 36 -position, Level III system. nvestment plus the flexibility to expand
into a full, 36 -position, Level ill system. mobile cabinet that is easily wheeled from room to room. A budget-saving alternative to the dedicated classroom. 4

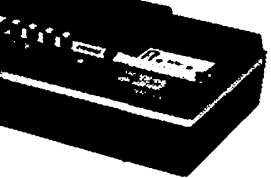

C-120 
June 27-July 1

Fifth International Conference on Nordic Languages and Modern Linguistics in Arhus, Denmark.

Information: K. Ringgaard, Institute for Nordic Languages and Literature, Niels Juelsgade 84, DK-8200 Arhus N, Denmark.

July 4-6

Third European Congress of the International Reading Association (IRA) in Vienna, Austria.

Theme: How Teachers Learn to Teach Reading.

Information: Internationales Institut fuer Jugendliteratur und Leseforschung, Mayerhofgasse 6, A-1040 Wien, Austria.

\section{July 4 - August 12}

TESOL (Teachers of English to Speakers of Other Languages) Summer Institute in Toronto, Canada.

Information: J.P.B. Allen, Modern Language Centre, Ontario Institute for Studies in Education, 252 Bloor Street West, Toronto, Ontario M5S 1V6, Canada.

\section{July 18-22}

Second International Conference of the Department of Psychology and the School of Education, University of Bristol, Great Britain.

Theme: Social Psychology and Language.

Information: School of Education, University, 35 Berkeley Square, Bristol B58 1JA, Great Britain.

\section{July 21-23}

International Colloquium on Translation and Interpreting in Saarbruecken, Federal Republic of Germany.

Theme: Translating and Interpreting.

Information: W. Wilss, Fachrichtung Angewandte Sprachwissenschaften, University, D-6600 Saarbruecken, Federal Republic of Germany.

\section{July 26-August 4}

Fourth Triennial World Conference on Education of the World Council for Curriculum and Instruction (WCCl) in Edmonton, Canada.

Theme: Education for a Just Social and Economic Order: Rhetoric or Reality?

Information: WCCl, Office of the Dean, 845 Education South, University of Alberta, Edmonton 16C 2G5, Canada.

\section{August 1-5}

Seventh International Congress of the International German Teachers' Association (IDV) in Budapest, Hungary.

Theme: The Teaching of German in a Foreign-Language Environment.

Information: P. Basel, T.I.T., H-1367 Budapest 5, Pf. 123, Hungary. 


\section{August 1-6}

Tenth International Congress of Phonetic Sciences in Utrecht, The Netherlands.

Theme: Speech acoustics and speech processing systems, speech production, speech perception, speech and language, applicationoriented speech research.

Information: Professor Dr. A. Cohen, Department of Phonetics, University, Oudenoord 6, NL-3513 ER Utrecht, The Netherlands.

\section{August 2-6}

Fifth World Conference of Gifted and Talented Children, Youth and Adults in Manila, Philippines.

Information: Manila Cifted Conference, P.O. Box 639, Greenhills 3113, Metro Manila, Philippines.

\section{August 8-12}

International Joint Conference on Artificial Intelligence in Karlsruhe, Federal Republic in Germany.

Information: J. Siekmann, G. Wrightson, Institut fuer Informatik, University, Postfach 6380, D-7500 Karlsruhe, Federal Republic of Germany.

\section{August 9-13}

American Language Academy Seminar on Computer-Assisted Instruction for Individualized Language Teaching in Boston, Massachussetts, USA.

Information: American Language Academy, Suite 200, 11426 Rockville Pike, Rockville, Maryland 20852, USA.

\section{August 14-18}

Conference of the American Association of Teachers of Spanish and Portuguese (AATSP) in Boston, Massachusetts, USA.

Information: R. Klein, AATSP, Holy Cross College, Worcester, Massachusetts 01610, USA.

\section{August 16-21}

Fourth World Congress of Phoneticians (Speechology Congress) in Tokyo, Japan.

Theme: Speechology and Human Welfare.

Information: Phonetic Society of Japan, 12-13, Daita-2, Setegaya, Tokyo-155, Japan. 
August 19-21

Sixteenth Annual Meeting of the European Linguistic Society (Societas Linguistica Europaea) in Poznan, Poland.

Information: Professor Dr. J. Fisiak, Instytut Filologii Angielskiej, University, ul. Marchlewskiego 124/126, PL-61-874 Poznan, Poland.

\section{August 22-26}

Sixth International Conference of the International Society for Historical Linguistics in Poznan, Poland.

Information: Professor Dr. J. Fisiak, Instytut Filologii Angielskiej, University, ul. Marchlewskiego 124/126, PL-61-874 Poznan, Poland.

\section{August 22-27}

Eighth Congress of the International Association of Scholars of Spanish in Providence, Rhode Island, USA.

Information: A.D. Kossoff, Box E, Brown University, Providence, Rhode Island 02912, USA.

September: dates to be announced Information Processing Congress in Paris, France.

Information: M. Hermieu, 6, Place de Valois, F-75001 Paris, France.

September: dates to be announced

Third International Symposium of Textbook Authors in the Field of German as a Foreign Language in Sangershausen, German Democratic Republic.

Information: Komitee fur den Sprachunterricht in der DDR, Humboldt-University, Clara-Zetkin-Strasse 1, DDR-108 Berlin, German Democratic Republic.

\section{September 6-9}

Fifteenth International Colloquium of AIMAV (Association Internationale pour la Recherche et la Diffusion des Methodes Audio-Visuelles et Structuro-Globales) in Nijmegen. The Netherlands.

Theme: New Approaches in Foreign-Language Methodology.

Information: H. Bours, Department of Applied Linguistics, Catholic University, Erasmusplein 1, NL-6500 HD Nijmegen, The Netherlands.

September 9-12

International Congress on all Aspects of Lexicography in Exeter, Great Britain.

Theme: The Bilingual/Historical/Learner's Dictionary; Terminology Standardization; Computer-Aided Lexicography.

Information: Dr. R.R.K. Hartmann, The Language Centre, University, Exeter, Devon EX4 4HQ, Great Britain. 


\section{September 13-15}

First International Cable and Satellite Television Exhibition - CAST 83 - in Birmingham, United Kingdom.

Information: Conferences and Exhibitions International, Wardrobe Chambers, 146 A Queen Victoria Street, London EC4B 4BD, United Kingdom.

\section{September 20-24}

Third National Linguistic Congress of the Linguistic Society of Argentina (SAL) in Cooperation with the Argentinian Association.

Additional conferences of interest to our readers. All of the following conferences are sponsored by the Society for Applied Learning Technology (SALT). SALT's address is: 50 Culpepper Street, Warrenton, VA 22186 . (703) 347-0055.

June 23-24

Third Conference on Microcomputers in Education and Training in Arlington, VA.

July 13-14

Second Conference on Technology of Training Evaluation and Productivity Assessment in Arlington, VA.

\section{August 24-26}

Fifth Annual Conference on Video Learning Systems in Arlington, VA. 


\section{CALL FOR PAPERS \\ ON \\ APPLICATIONS OF TECHNOLOGY TO GERMAN \\ LANGUAGE TEACHING}

The Spring 1984 issue of DIE UNTERRICHTSPRAXIS will focus on recent developments in instructional technology as applied to the teaching of German. Papers on the following and related topics are solicited:

-CAI, CMI, \& computer text editing in instruction

-television, videotape, CATV and satellite reception

-videodisc

-audio tape and radio

-speech synthesis, recognition, and diagnosis by automated means

-film, slide, filmstrip, and other projected media

-merging and integration of multiple technologies

-language media centers

-evaluation of media

Papers describing non-German applications will be considered if German-language examples and utilization can be provided. In addition, a special section will be devoted to brief descriptions of available courseware and media materials.

DEADLINE FOR RECEIPT OF PAPERS: SEPTEMBER 1, 1983

Inquiries on possible topics are welcome and should be directed to the guest editor.

Renate Schultz, Editor

Dept. of German

University of Arizona

Tuscon, AZ 85721

(602) 626-3245
James P. Pusack, Guest Editor

Dept of German

University of lowa

lowa City, IA 52242

(319) $353-4937$ (o)

(319) 338-1552 (h)

JOB OPENING ANNOUNCEMENT

The University of Southern Illinois at Carbondale (SIUC) is seeking a Language Laboratory Director. Responsibilities include supervising the installation of new equipment, maintenance of onboard equipment, and demonstrating creativity in developing lab programs. An advanced degree along with second language teaching experience are desired. This is professional administrative position with a 12 month appointment. Application deadline is April 1, 1983, or until the position is filled. For information contact: Dr. Helmut Liedloff, Chair, Dept of Foreign Langyages \& Literatures, Southern Illinois University, Carbondale, ILL 62901. (618) 536-5571. 